Katarzyna Wojtanowicz

Uniwersytet Papieski

Jana Pawła II

w Krakowie
Eliminacja wykluczenia społecznego, red. M. Duda, K. Kutek-Sładek, Kraków 2017, s. 177-185 (Praca Socjalna w Teorii i Działaniu, 3).

DOI: http://dx.doi.org/10.15633/9788374385824.12

\title{
Środowiskowa praca socjalna na rzecz rozwoju społecznego
}

\author{
Environmental social work for social development
}

\begin{abstract}
The implementation of social of individual students man is not without work focus on implementation on the basis of three methods: working with individual case, group and community. While the first two methods are commonly used in social work, the environmental social work is in the phase of implementation and development. In the era of economic development, new technologies and the growing needs significance is the need to build and integrate social environment. Social capital in translating the functioning of civil society is an important element of strength and quality of each community.

Keywords: environmental social work, community organizing
\end{abstract}

W dobie rozwoju gospodarczego, nowych technologii i wzrastających potrzeb indywidualnych człowieka nie bez znaczenia jest potrzeba budowania i integrowania środowiska społecznego. Kapitał społeczny w przełożeniu na funkcjonowanie obywatelskie stanowi istotny element siły i jakości każdej społeczności. Współczesna polityka społeczna, aby osiągnąć zrównoważony poziom rozwoju społecznego, szczególnie w zakresie pomocy społecznej, to jest w stosunku do osób słabszych, niepełnosprawnych, wymagających wsparcia i pomocy, musi zastosować mechanizmy aktywnej polityki, tj. takiej, która angażuje wszystkie zasoby instytucjonalne, organizacyjne, materialne, a przed wszystkim osobowe. W tym wymiarze bardzo ważną rolę odgrywa kapitał społeczny, który $\mathrm{z}$ jednej strony może realizować szereg działań środowiskowych, z drugiej zaś 
samorealizować swój proces wprowadzania zmiany i rozwoju. Jak wskazuje Marek Rymsza, organizowanie społeczności lokalnej (OSL) jest ustrukturyzowaną metodą pracy środowiskowej, głownie ze społecznościami marginalizowanymi, zaniedbanymi, mającymi pewien potencjał rozwoju, który wymaga jednak wzmocnienia i uruchomienia przez interwencję z zewnątrz. Jest to zadanie organizatora społeczności lokalnej, podejmującego działania z zakresu animacji lokalnej, organizowania sieci społecznych i planowania społecznego ${ }^{1}$.

Środowisko lokalne obok rodziny stanowi istotny czynnik rozwoju i socjalizacji każdego człowieka. To również w środowisku lokalnym kształtują się tradycje, wartości, kultura, co stanowi istotny element przynależności terytorialnej, gotowej do podejmowania wspólnych działań opartych na przynależności.

\section{1. Środowiskowa metoda pracy socjalnej- zagadnienia ogólne}

Metoda środowiskowa pracy socjalnej, zwana organizowaniem społeczności lokalnej w pracy socjalnej, została zapoczątkowana w 1946 roku, gdy w Stanach Zjednoczonych powstało Amerykańskie Towarzystwo do Badań nad Organizowaniem Środowiska Lokalnego ${ }^{2}$. Metoda pracy ze społecznością lokalną obejmuje swoim zasięgiem całe środowisko lokalne wymagające wzmocnienia, wypracowania zmian w jego strukturze i funkcjonowaniu poprzez optymalne wykorzystanie jego zasobów. Zasoby te koncentrują się wokół sił, środków, potencjału ludzkiego i instytucjonalnego. Metoda ta kierunkuje się na skupienie uwagi na całej społeczności i oddziaływania na jej rzecz z wykorzystaniem zasobów indywidualnych członków grupy, całej grupy, jak i instytucjonalnych.

Organizowanie społeczności lokalnej skupia się zatem na mobilizowaniu do działania grup i zbiorowości terytorialnych w zakresie rozpoznawania i aktywnego realizowania swoich potrzeb. Społeczność jest tu zatem definiowana jako:

1. wspólnota miejsca zamieszkania, lokalna - tworząca wspólnotę terytorialną, np. sąsiedztwo, osiedle, miasteczko, wieś;

2. wspólnota interesów, kategorialna - mająca wspólną potrzebę do zaspokojenia, problem do rozwiązania, np. rodzice dzieci z niepełnosprawnością, osoby chorujące psychicznie, opiekunowie osób starszych ${ }^{3}$.

1 Organizowanie społeczności lokalnej: aplikacje, wdrażanie, przyszłość, red. T. Kazimierczak, Warszawa 2014, s. 32.

2 M. Adamczyk, Organizowanie społeczności lokalnej jako wyzwanie dla wspótczesnej pracy socjalnej, [w:] Szkice o pracy socjalnej, red. J. Mazur, Lublin 2009, s. 89.

3 K. Wódz, B. Kowalczyk, Organizowanie społeczności. Modele i strategie działania, Warszawa 2014, s. 15. 
Organizowanie społeczności lokalnej to przede wszystkim praca nad poprawą funkcjonowania, w oparciu o zjednoczone siły społeczne i publiczne oraz wspólnie wypracowany plan ${ }^{4}$.

Teoria środowiskowej pracy socjalnej bazuje na podejściu systemowym, które zakłada, że każdy człowiek przynależy do jakiejś grupy społecznej, rodziny, tworząc współzależność. Kazimiera Wódz za Jackiem Rothmanem wyodrębniła pięć odmian w podejściu do pracy środowiskowej:

1. podejście strukturalne - koncentrujące się na wymiarze politycznym i terytorialnym funkcjonowaniu społeczności lokalnej (analiza nierówności społecznych, struktury władzy i stratyfikacji społecznej),

2. podejście psychospołeczne - koncentrujące się na subiektywnym, kulturowym wymiarze funkcjonowania społeczności (analiza postaw, opinii, wzorców zachowań, wartości, norm i zwyczajów),

3. podejście ekologiczno-demograficzne - koncentruje się na analizie przestrzenno-społecznych aspektów funkcjonowania społecznego (rozmieszczenie ubóstwa, bezrobocia, patologii),

4. podejście funkcjonalne - podejmuje analizę społeczności z ukierunkowaniem na zdefiniowanie potrzeb danej społeczności,

5. podejście systemowe - ujmuje społeczność jako złożony układ powiązanych ze sobą podsystemów ${ }^{5}$.

$\mathrm{Z}$ analizy powyższych wskazań wynika, że praca ze społecznością lokalna wymaga od osób ją realizujących wysokich kompetencji. Organizatorem społeczności lokalnej jest specjalista prowadzący ten proces w społeczności, ze społecznością i dla społeczności. Odnosząc tę rolę do realizacji zadań w obszarze pomocy społecznej, jest to np. pracownik socjalny. Organizator społeczności lokalnej jako inicjujący działania podejmuje je:

- w oparciu o faktyczne potrzeby ludzi mieszkających na danym obszarze i ich bezpośrednie doświadczenia;

- inspirując i mobilizując mieszkańców do podejmowania samodzielnych działań jako grupa, prowadzących do nabycia przez społeczność zdolności rozwiązywania własnych problemów;

- budując sieć współpracy w postaci partnerstwa tworzonego przez instytucje i organizacje mające wpływ na daną społeczność;

- realizując powyższe działania, dany specjalista staje się animatorem społeczności lokalnej.

$4 \quad$ K. Wódz, Praca socjalna w środowisku zamieszkania, Katowice 1998, s. 151

$5 \quad$ K. Wódz, Praca socjalna w środowisku zamieszkania, dz. cyt., s. 151-152. 


\section{Organizator społeczności lokalnej jako animator społeczny}

Organizator społeczności lokalnej, podejmując rolę animatora społecznego/ lokalnego realizuje swoja pracę w wybranej społeczności lokalnej, sprawnie zorganizowanej i działającej, ukierunkowanej na osiągnięcie założonych celów. Są to tak zwane grupy zadaniowe, dążące świadomie do rozwiązania konkretnych problemów. Choć odgrywa on rolę drugoplanową, to jest ona bardzo istotna.

Do podstawowych zadań animatora społeczności lokalnej należy:

- ułatwianie kontaktów, prowadzenie do lepszego poznania się mieszkańców oraz tworzonych przez nich grup i środowisk;

- animowanie wśród mieszkańców dyskusji dotyczących ważnych aspektów życia codziennego, a zwłaszcza nierozwiązanych lokalnych problemów;

- wyszukiwanie i wspieranie liderów lokalnych;

- diagnozowanie potencjału lokalnego środowiska;

- inicjowanie powstawania grup obywatelskich;

- motywowanie grup i środowisk do podejmowania aktywności ukierunkowanych na dobro wspólne;

- budowanie lokalnych koalicji;

- moderowanie sytuacji edukacyjnych w środowisku;

- pobudzanie energii potrzebnej do podjęcia i podtrzymania działania przez osobę (grupę) 6 .

Rola animatora społecznego jest często przypisywana pracownikom służb społecznych, głównie pracownikowi socjalnemu. Jest on faktycznie wprost predysponowany do podejmowania takiej roli. Pracownik socjalny na etapie edukacji przygotowywany jest do podejmowania takiej roli zawodowej. Praca środowiskowa jest również coraz szerzej podejmowana i realizowana przez organizacje pozarządowe działające w trzecim sektorze. Szeroki wachlarz działań gwarantuje im ustawa o pożytku publicznym i wolontariacie ${ }^{7}$.

Pełnienie roli organizatora społeczności lokalnej wymaga konkretnej wiedzy, szeregu kompetencji i umiejętności. Do najważniejszych kompetencji należą umiejętności: diagnozowania, planowania, organizacyjne, mediacyjne i negocjacyjne, komunikacyjne; samodzielność w działaniu i umiejętność pracy zespołowej, znajomość procesu grupowego oraz otwartość na budowanie relacji międzyludzkich.

6 T. Kazimierczak i in., Środowiskowe role pracownika socjalnego, Warszawa 2013, s. 17.

Więcej: Ustawa z dnia 24 kwietnia 2003 r. o działalności pożytku publicznego i o wolontariacie, Dz.U. $2003 \mathrm{Nr} 96$ poz. 873 ze zm. 
Rolą animatora społecznego jest aktywizowanie społeczności lokalnej bez osobistego przejmowania przez niego funkcji przywódczej. To znaczy, że sam nie podejmuje on działań, a jedynie je stymuluje i kierunkuje na realizację złożonych celów. Jego rola jest więc aktywna, a nie dyrektywna. Pomaga poprzez edukowanie, inspirowanie, motywowanie, wspieranie procesu zmiany, zaspakajanie potrzeb jednostkowych i społecznych ${ }^{8}$.

\section{Etapy i narzędzia pracy metoda organizowania społeczności lokalnej}

Organizowanie społeczności lokalnej jako metoda środowiskowej pracy socjalnej metodycznie przebiega według określonych etapów, składających się na zaplanowany proces oddziaływań:

1. zbieranie informacji,

2. ocena sytuacji,

3. zachęcanie ludzi do spotkania się w celu podjęcia decyzji, jakim problemem chcą się zająć,

4. tworzenie i wspieranie grupy (kampanii, koalicji),

5. pomaganie grupie (kampanii, koalicji) w planowaniu jej strategii i taktyk oraz określaniu priorytetów działań,

6. umacnianie i podtrzymywanie grupy (kampanii, koalicji), gdy zaczyna realizować działania,

7. dokonywanie przeglądu postępów i działań grupy (kampanii, koalicji),

8. pomaganie grupie (kampanii, koalicji) w zakończeniu działań lub podjęciu decyzji, co dalej.

Tak zaplanowany proces w swojej realizacji nie musi się kończyć. Wręcz przeciwnie, po szeregu wzmacniających doświadczeń i pozytywnej zmianie zaczyna się od początku.

Strategia konsensusu i współdziałania jest najbardziej przydatną i skuteczną strategią wpływającą na wywoływanie pozytywnych trwałych zmian w społecznościach lokalnych. W związku z tym powinna stanowić podstawę działań organizatora społeczności lokalnej, jeśli to tylko możliwe. Bazuje ona na założeniu, że podejmowane w społeczności lokalnej działania powinny odpowiadać na jej rzeczywiste problemy i potrzeby, zaś w proces zmian należy włączać lokalne zasoby ludzkie oraz instytucjonalne. Zakłada się przy tym nie tylko aktywny udział, ale również współdziałanie, zatem budowanie sieci współpracy jest jednym z podstawowych celów zaangażowania organizatora społeczności

8 Pracownicy socjalni i praca socjalna w Polsce, red. M. Rymsza, Warszawa 2012, s. 208. 
lokalnej. Podstawą działań realizowanych w oparciu o strategię konsensusu i współdziałania jest planowanie i praca metodą projektów, zwłaszcza animacyjnych, których kierunek wyznacza diagnoza oparta na badaniu i działaniu. Narzędziami wykorzystywanymi podczas realizacji tej strategii są: spotkania z mieszkańcami, różnego rodzaju grupy, budowanie sieci współpracy, w tym lokalne partnerstwa ${ }^{9}$. Do grupy narzędzi wspierających proces zmian zalicza się: partnerstwo lokalne, wolontariat, grupy, kampanie społeczne i wydarzenia oraz rzecznictwo i informację obywatelską.

Istotną rolę w organizowaniu społeczności lokalnej odgrywają działania realizowane w partnerstwie, zawiązanym w sposób bardziej lub mniej sformalizowany. Możemy wymienić następujące modele zawieranych partnerstw:

- partnerstwa publiczno-prywatne (społeczne), zawierane pomiędzy instytucjami publicznymi, podmiotami prywatnymi (społecznymi) w celu realizacji określonych działań, najczęściej ze sfery publicznej;

- partnerstwo projektowe, tworzone w zakresie realizacji określonych działań projektowych;

- partnerstwo lokalne, sektorowe (np. publiczne, społeczne, prywatne), podmioty kościelne, naukowe, grupy nieformalne, również o charakterze klastra społecznego. Porozumienie instytucji i organizacji, które chcą działać na rzecz wspólnego celu, również we wzajemnym uzupełnianiu się.

Ukierunkowanie skutecznych działań w oparciu o współdziałanie w partnerstwie przynosi bardzo wymierne korzyści. Nie sposób je przecenić. Wymaga to jednak nie tylko determinacji w wypracowywaniu reguł współdziałania, ale i również ciągłego monitorowania.

\section{Budowanie partnerstw - reguła pięciu kroków}

Krok 1 jest związany z określeniem problemów (potrzeb), których rozwiązaniu (zaspokojeniu) winno służyć partnerstwo, rozpoznaniem i analizą lokalnych zasobów ludzkich i instytucjonalnych, pod kątem ich ewentualnego włączenia we wspólne działania oraz wypracowanie wstępnej wizji przyszłego partnerstwa.

Krok 2 wiąże się z przeprowadzeniem rozmów z potencjalnymi partnerami celem przekonania do idei partnerstwa i namówienia do włączenia się we wspólne działania oraz zaproszenia ich na spotkanie (należy pamiętać, żeby nie zrażać do siebie osób, które nie wyraziły chęci współdziałania).

Krok 3 to spotkanie z potencjalnymi partnerami, służące wzajemnemu poznaniu się, ustaleniu celu i zasad współdziałania, określeniu modelu i kształtu partnerstwa oraz roli poszczególnych partnerów i ich oczekiwań. Najczęściej te sprawy są omawiane, ustalane podczas kilku kolejnych spotkań, a pierwsze

9 B. Bąbska, M. Rymsza, Organizowanie społeczności lokalnej - metodyka pracy środowiskowej. Poradnik II, Warszawa 2014, s. 20-21. 
spotkanie służy bardziej wzajemnemu poznaniu się i podjęciu przez poszczególnych partnerów decyzji o ewentualnej współpracy; podczas następnych spotkań z osobami, które zadeklarowały udział w partnerstwie, ustalane są cele i zasady partnerstwa.

Krok 4 jest związany z wypracowywaniem strategii działania partnerstwa i planów działania oraz ustaleniem spraw związanych z logistycznym zabezpieczeniem działań partnerstwa (zaplecze lokalowe, obsługa, przepływ informacji itp.).

Krok 5 wiąże się z realizacją i monitorowaniem zaplanowanych działań. Ważny w tym zakresie jest równomierny rozkład zadań między poszczególnymi partnerami ${ }^{10}$.

Partnerstwo, współdziałanie, interdyscyplinarność w podejmowaniu działań w zakresie pracy środowiskowej to podstawowe jej filary. Bez takiego podejścia realizacja tej metody nie jest możliwa.

\section{Podsumowanie}

Ciągłe kierunkowanie systemu pomocowego wymusza zwiększenie zaangażowania samych zainteresowanych osiągnięciem zmiany. System pomocy ewoluuje od pasywnego w kierunku aktywnego. W tym kierunku podąża również wykorzystywanie we współczesnej pracy socjalnej oraz szerzej w polityce społecznej metody pracy środowiskowej - organizowanie społeczności lokalnej, animacja społeczna. Wykorzystanie jej, jak pokazuje praktyka, przynosi bardzo wymierne korzyści. Po latach koncentracji na pracy z indywidualnym przypadkiem i grupą nastała era realizacji trzeciej metody pracy socjalnej - metody środowiskowej. Współczesna praca socjalna powinna być ukierunkowana na niesienie pomocy, która przyczyni się do odzyskania lub wzmocnienia zdolności do samodzielnego funkcjonowania w społeczeństwie. Praktycy, badacze i politycy społeczni ciągle poszukują rozwiązań, które wpłyną na podniesienie efektywności działań, jakie są i będą podejmowane przez instytucje pomocy społecznej, w tym pracownika socjalnego, jak również ograniczą skalę udzielanej pomocy. Starając się stworzyć nowy model pomocy społecznej w Polsce, zadeklarowano, że ma ona pełnić rolę kompensacyjną wobec innych systemów zabezpieczenia społecznego. Świadczenia pieniężne mają mieć charakter uzupełniający w stosunku do systemu ubezpieczeń społecznych i wypełniać luki powstałe na jego obrzeżach. Oznacza to, że zgodnie z ustrojową zasadą subsydiarności pomoc społeczna stanowiłaby

10 Z. Wejcman, G. Gnatowska, Partnerstwo. Rola i proces tworzenia, Warszawa 2005, s. $12-15$. 
ostatnie ogniwo w całym systemie rozwiązań służących budowaniu bezpieczeństwa socjalnego i ładu społecznego.

Przykłady realizacji środowiskowej pracy socjalnej zdecydowanie wskazują na efektywność jej zastosowania. Duże ukierunkowanie na wykorzystanie tej metody do projektów, w tym przygotowania i realizacji projektów socjalnych, dodatkowo podkreśla jej walory.

Nie bez znaczenia jest również umiejętność animacji społecznej we wprowadzaniu podjętych w ostatnim czasie przez wiele samorządów w Polsce tzw. budżetów obywatelskich. Partycypacja i zaangażowanie społeczne wymagają odpowiedniego poziomu przygotowania, budowania dojrzałości i kompetencji w tym zakresie. Również poprzez edukację i doświadczenie wyłaniają się swoiści liderzy społeczni, którzy są ważnym ogniwem rozwoju i „siły” społecznej.

Działania w obszarze organizacji społeczności lokalnej wpisują się zatem w dyskurs zarówno naukowy, jak i gospodarczo-polityczny. Nabiera on szczególnego znaczenia w dobie nasilających się problemów społecznych, szczególnie migracyjnych, gdzie zaangażowania wymaga potrzeba asymilacji dużych grup imigrantów pojawiających się w Europie.

Dobrze funkcjonujące społeczności lokalne stanowią kapitał społeczny, który wywołuje rozwój lokalny w oparciu o własne zasoby. Stymulując ten rozwój, zaspokajają samodzielnie swoje potrzeby. Równie ważny jest rozwój społeczności mającej ograniczone możliwości samodzielnego zabezpieczenia swoich potrzeb. W tym przypadku animacja społeczna buduje zasoby, które ukierunkowane są na rozwój jednostek, który również przynosi ład społeczny - rozwój społeczny. Ludzkie problemy i potrzeby wywoływane są w interakcji zachodzącej pomiędzy człowiekiem a jego środowiskiem życia. Zatem każda podjęta próba zmiany tego środowiska ma bardzo duże znaczenie.

\section{Bibliografia}

Adamczyk M., Organizowanie społeczności lokalnej jako wyzwanie dla wspótczesnej pracy socjalnej, [w:] Szkice o pracy socjalnej, red. J. Mazur, Lublin 2009.

Bąbska B., Rymsza M., Organizowanie społeczności lokalnej - metodyka pracyśrodowiskowej. Poradnik II, Warszawa 2014.

Kazimierczak T. i in., Środowiskowe role pracownika socjalnego, Warszawa 2013.

Organizowanie społeczności lokalnej: aplikacje, wdrażanie, przyszłość, red. T. Kazimierczak, Warszawa 2014. 
Pracownicy socjalni i praca socjalna w Polsce, red. M. Rymsza, Warszawa 2012.

Wejcman Z., Gnatowska G., Partnerstwo. Rola i proces tworzenia, Warszawa 2005.

Wódz K., Kowalczyk B., Organizowanie społeczności. Modele i strategie działania, Warszawa 2014.

Wódz K., Praca socjalna w środowisku zamieszkania, Katowice 1998. 
4. Uniwersytet Papieski 